\title{
Hypothalamic, Metabolic, and Behavioral Responses to Pharmacological Inhibition of CNS Melanocortin Signaling in Rats
}

\author{
Tiziana Adage, ${ }^{1}$ Anton J. W. Scheurink, ${ }^{1}$ Sietse F. de Boer, ${ }^{1}$ Koert de Vries, ${ }^{1}$ Jan Pieter Konsman, ${ }^{2}$ \\ Folkert Kuipers, ${ }^{3}$ Roger A. H. Adan,, ${ }^{4}$ Denis G. Baskin, ${ }^{5,7}$ Michael W. Schwartz, ${ }^{6}$ and Gertjan van Dijk ${ }^{1}$
}

${ }^{1}$ Department of Animal Physiology, University of Groningen, 9750 AA Haren, the Netherlands, 2Department of Biomedicine and Surgery, Faculty of Health Sciences, University of Linköping, 58185 Linköping, Sweden, ${ }^{3}$ Centre for Liver, Digestive, and Metabolic Diseases, Department of Pediatrics, University Hospital, 9713GZ Groningen, the Netherlands, ${ }^{4}$ Department of Medical Pharmacology, Rudolph Magnus Institute, University of Utrecht, 3584CG Utrecht, the Netherlands, ${ }^{5}$ Department of Medicine and Biological Structure, University of Washington, ${ }^{6}$ Department of Medicine, University of Washington and Harborview Medical Center, Seattle, Washington 98104, and 'Veterans Affairs Medical

Center, Seattle, Washington 98108

The CNS melanocortin (MC) system is implicated as a mediator of the central effects of leptin, and reduced activity of the CNS MC system promotes obesity in both rodents and humans. Because activation of CNS MC receptors has direct effects on autonomic outflow and metabolism, we hypothesized that food intake-independent mechanisms contribute to development of obesity induced by pharmacological blockade of MC receptors in the brain and that changes in hypothalamic neuropeptidergic systems known to regulate weight gain [i.e., corticotropinreleasing hormone $(\mathrm{CRH})$, cocaine-amphetamine-related transcript (CART), proopiomelanocortin (POMC), and neuropeptide $Y$ (NPY)] would trigger this effect. Relative to vehicle-treated controls, third intracerebroventricular (i3vt) administration of the MC receptor antagonist SHU9119 to rats for $11 \mathrm{~d}$ doubled food and water intake (toward the end of treatment) and increased body weight $(\sim 14 \%)$ and fat content $(\sim 90 \%)$, hepatic glycogen content $(\sim 40 \%)$, and plasma levels of cholesterol $(\sim 48 \%)$, insulin ( $259 \%)$, glucagon $(\sim 80 \%)$, and leptin $(\sim 490 \%)$, whereas spontaneous locomotor activity and body temperature were reduced. Pair-feeding of i3vt SHU9119-treated animals to i3vt vehicle-treated controls normalized plasma levels of insulin, glucagon, and hepatic glycogen content, but only partially reversed the elevations of plasma cholesterol $(\sim 31 \%)$ and leptin $(\sim 104 \%)$ and body fat content $(\sim 27 \%)$. Reductions in body temperature and locomotor activity induced by i3vt SHU9119 were not reversed by pair feeding, but rather were more pronounced. None of the effects found can be explained by peripheral action of the compound. The obesity effects occurred despite a lack in neuropeptide expression responses in the neuroanatomical range selected across the arcuate (i.e., CART, POMC, and NPY) and paraventricular (i.e., $\mathrm{CRH}$ ) hypothalamus. The results indicate that reduced activity of the CNS MC pathway promotes fat deposition via both food intake-dependent and -independent mechanisms.

Key words: obesity; SHU9119; NPY; CRH; POMC; CART; cholesterol; leptin; hypothalamus; body temperature
With the discovery of leptin by Zhang et al. (1994) and its receptors in the CNS, a long-sought feedback mechanism was established linking adiposity to CNS regulation of body weight homeostasis. The brain melanocortin (MC) system-with $\alpha$-melanocyte-stimulating hormone ( $\alpha$-MSH) and agouti-related protein (AgRP) as agonists and antagonists, respectively, of brain MC receptors-is implicated in the signaling cascade used by leptin in the CNS. For example, reduced food intake that occurs after third intracerebroventricular (i3vt) leptin administration was effectively blocked by coadministration of the mixed MC3/4receptor antagonist SHU9119 (Seeley et al., 1997). In addition, the stimulatory effects of leptin on uncoupling protein synthesis

Received July 26, 2000; revised Feb. 12, 2001; accepted March 2, 2001.

This work was supported by grants from the School of Behavioral and Cognitive Neurosciences (BCN-331026), the Dutch Scientific Organization (NWO-903-39157), the Royal Dutch Academia of Sciences, Merit Review Program of the Department of Veteran Affairs, and the National Institutes of Health (NS-32273 and DK-53109, -17844, -12829, and -6339). We thank J. E. Bruggink, V. Bloks, E. Colasurdo, S. Reed, and H. Nguyen for excellent technical assistance.

Correspondence should be addressed to Gertjan van Dijk, Department of Animal Physiology, P. O. Box 14, 9750 AA Haren, the Netherlands.

E-mail: g.van.dijk@biol.rug.nl.

Copyright $\odot 2001$ Society for Neuroscience $0270-6474 / 01 / 213639-07 \$ 15.00 / 0$ in peripheral tissue (Satoh et al., 1998) and sympathetic renal nerve traffic (Haynes et al., 1999) was shown to be blocked by central MC receptor antagonism. Complementary to these effects were findings by our (Schwartz et al., 1997; van Dijk et al., 1999) and other groups (Thornton et al., 1997) that leptin stimulates proopiomelanocortin (POMC; precursor peptide from which $\alpha$-MSH is cleaved) synthesis in neuronal cell bodies of the arcuate hypothalamic nucleus.

In concert with the notion that brain melanocortins are involved in leptin signaling are observations that overproduction of the endogenous MC receptor antagonist agouti, or AgRP (Yen et al., 1994; Miltenberger et al., 1997), and targeted mutations of MC receptors (Huszar et al., 1997) or of POMC (Yaswen et al., 1999) lead to hyperphagia and increased fat deposition in rodents, and thus play an essential role in energy homeostasis. Consequences of reduced MC receptor activity may be clinically relevant because both polymorphisms (Comuzzie et al., 1997; Hixson et al., 1999) and mutation (Krude et al., 1998) of the POMC gene locus, as well as mutation of MC4 receptors (Hinney et al., 1999; Cheng and Garg, 1999; Gu et al., 1999), are linked with human obesity. Pharmacological evidence for a role of MC receptors in body weight homeostasis in rats was provided by Skuladottir et al. 
(1999), who reported that $7 \mathrm{~d}$ i3vt treatment with the MC4-R antagonist HS014 increases food intake and body weight.

Because CNS MC receptor activation increases metabolic rate (Cornelius et al., 1999), we hypothesized that weight gain induced by central blockade of MC receptors is mediated by both food intake-dependent and -independent mechanisms. Such a food intake-independent contribution to obesity has recently been observed in MC4 knock-out mice (Ste. Marie et al., 2000). To test this hypothesis, rats were infused i3vt (or peripherally) either with SHU9119 or vehicle over an $11 \mathrm{~d}$ period using osmotic minipumps. Meanwhile, effects on food and water intake, body weight and temperature, spontaneous activity, and stored and circulating levels of fuels and hormones were assessed. An additional group of i3vt SHU9119-treated animals was pair-fed to controls such that the amount of food provided to these animals was equal to the amount consumed by the vehicle-treated group. This pair-fed group permitted investigation of the effects of reduced CNS MC receptor activity on energy balance via mechanisms independent of food intake.

In addition to $\alpha-\mathrm{MSH}$, a number of other hypothalamic neuropeptides are known to be involved in the regulation of energy balance. These include, for example, corticotropin-releasing hormone (CRH) (Hotta et al., 1991; Buwalda et al., 1997), neuropeptide Y (NPY) (Stanley et al., 1986; Zarjevski et al., 1993), and cocaine-amphetamine-related transcript (CART) (Kristensen et al., 1998). The activity of these neuropeptide systems is controlled by leptin (for review, see Schwartz et al., 2000), and possibly by melanocortins as well (Kesterson et al., 1997; Kask et al., 1998; Marsh et al., 1999; King et al., 2000). We hypothesized that chronic i3vt SHU9119 treatment can stimulate orexigenic and/or inhibit anorexigenic pathways, therefore hypothalamic expression levels of CRH, CART, NPY, and POMC were assessed relative to vehicle-treated controls.

\section{MATERIALS AND METHODS}

Animal preparation. Adult male Wistar rats obtained from the breeding colony maintained by the Department of Animal Physiology at the University of Groningen, weighing between 420 and 470 gm (between 5 and 6 months of age) were used. They were individually housed in Plexiglas cages $(25 \times 25 \times 30 \mathrm{~cm})$ on a layer of wood shavings, under controlled temperature $\left(21 \pm 1^{\circ} \mathrm{C}\right)$, relative humidity $(55-5 \%)$, and maintained on a $12 \mathrm{hr}$ light/dark cycle (lights on 5:00 A.M. to 5:00 P.M.). Animals were handled daily and weighed just before lights off. Food and water were provided ad libitum except where noted, and their intake was assessed daily. All methods and experiments were approved by the Animal Care Committee of the University of Groningen. Under $\mathrm{N}_{2} \mathrm{O}-$ halothane anesthesia, rats were implanted stereotaxically with a 22 gauge stainless steel guide cannula (Plastics One, Roanoke, VA) into the third ventricle (i3vt) as described elsewhere (van Dijk et al., 1996). Transmitters (model TA10TA-F40; Data Sciences, St. Paul, MN) for the measurement of body temperature and activity by radio telemetry were also implanted in the peritoneal cavity. Individual cages of animals were arranged on a radio receiver (model RA1010; Data Sciences), each attached via a BCM-100 consolidation matrix to a computerized data acquisition system (Dataquest IV, Data Sciences). This system allowed continuous assessment of body temperature and locomotor activity until the end of the experiment. After surgery, each rat received natriumbenzylpenicillin (100,000 IU) and was allowed to recover for at least $10 \mathrm{~d}$.

After they had regained normal growth rates and normal food and water intake for at least 1 week, animals $(n=14)$ were semirandomly divided into two groups that had the same mean body weight. Approximately $1 \mathrm{hr}$ before the dark phase, each rat (under $\mathrm{N}_{2} \mathrm{O}$-halothane anesthesia) had a osmotic minipump (Alzet 2002; Alza, Palo Alto, CA; pumping rate $0.55 \mu \mathrm{l} / \mathrm{hr}$ ) implanted subcutaneously and connected with a polyethylene tube (PE50) to an injector permanently placed into the guide cannula. In one group $(n=7)$, the pumps and connector tubing were filled to deliver sterile saline, whereas in the other group $(n=7)$ the pumps were filled to deliver SHU9119 (Fan et al., 1997) dosed at 0.5 $\mathrm{nmol} / \mathrm{d}$ with sterile saline as vehicle. After several days, a third group of animals $(n=7)$ matched for body weight to the control group was implanted with osmotic minipumps that were filled to deliver SHU9119 $(0.5 \mathrm{nmol} / \mathrm{d})$ as well. Each animal in this group received the same amount of food consumed by a control rat to which they were paired during the study. Food was given to these pair-fed rats at the beginning of the dark phase, $4 \mathrm{hr}$ later, and at the end of the overnight period. An additional group of animals received osmotic minipumps implanted in the abdominal cavity to deliver either saline $(n=5)$ or $0.5 \mathrm{nmol} \mathrm{SHU9119/d}(n=$ 5). These groups served to investigate whether any effect of SHU9119 on body weight, food intake, body temperature, and plasma hormone and fuel levels could be attributed to leakage of centrally administered SHU9119 to the periphery.

Assessment of food and water consumption and body weight. Starting $2 \mathrm{~d}$ before implantation of pumps, food hoppers were weighed at the beginning of the dark period, $4 \mathrm{hr}$ after, and at the end of the overnight period to assess food intake over the first $4 \mathrm{hr}$ of the dark phase, the final $8 \mathrm{hr}$ of the dark phase, and the food intake that occurred during the light phase. Water bottles and rats were weighed just before the dark phase. At the beginning of the dark phase, at $4 \mathrm{hr}$ into the dark phase and at the beginning of the light phase, pair-fed animals were provided with the same amount of chow that was consumed by the ad libitum feeding controls over the corresponding time intervals.

Body temperature and activity. Body temperature and gross locomotor activity were recorded by the biotelemetry system during the $2 \mathrm{~d}$ of basal (day $-2 /-1$ ) until the end of the experiment. The transmitter implanted intraperitoneally produced a temperature-dependent frequency-modulated signal received by the radio receiver located under the cage. Body temperature was sampled for $10 \mathrm{sec}$ every $5 \mathrm{~min}$, whereas activity was recorded continuously and sampled at 5 min intervals.

Locomotor activity was measured by monitoring the changes in the receiver signal strength that resulted from animal movement. To avoid differences in receiver sensitivity, the mean activity count value of the $2 \mathrm{~d}$ basal recording for each animal was considered as $100 \%$ activity for that animal. Activity counts were expressed as percentage of that value, and group averages were calculated on transformed data.

Blood and tissue collection and analyses. At the end of the dark cycle of day 10 , animals were taken from their home cages, anesthetized by brief $(<2 \mathrm{~min})$ exposure to $\mathrm{CO}_{2}$, and killed by decapitation. Immediately thereafter, brains were removed, and liver biopsies were taken and stored at $-80^{\circ} \mathrm{C}$. Trunk blood was collected in ice-cooled borosilicate tubes containing $350 \mu \mathrm{l}$ of aprotinin, 10,000 IU/ml, and EDTA $0.05 \mathrm{gm} / \mathrm{ml}$. Plasma samples (after centrifugation for $15 \mathrm{~min} 1500 \times \mathrm{g} 4^{\circ} \mathrm{C}$ ) were stored at $-80^{\circ} \mathrm{C}$. Blood glucose levels were measured by the ferricyanide method of Hoffman; plasma level of insulin, glucagon and leptin were measured by commercial radioimmunoassay kits (Linco Research; RI$13 \mathrm{~K}, \mathrm{GL}-32 \mathrm{~K}$, and RL-83K, respectively), plasma concentrations of triglycerides, free fatty acids, and total cholesterol were measured using commercial kits (Boehringer Mannheim, Mannheim, Germany), and plasma corticosterone was measured using HPLC with UV detector according to Dawson et al. (1984). Liver glycogen biopsies were cut (25-50 $\mathrm{mg}$ ) from frozen tissue, boiled for $2 \mathrm{hr}$ in $1 \mathrm{M} \mathrm{HCl}$ to facilitate glycogen breakdown. After $\mathrm{pH}$ neutralization, glucose concentrations were assessed in these samples, indicating the amount of initial glycogen in tissue.

Wet weight of eviscerated carcasses, livers, retroperitoneal and epididymal fat pads, and intestines including stomach (with and without contents) were assessed and stored at $75^{\circ} \mathrm{C}$ for several weeks. Fat content of eviscerated carcasses and different organs was determined by comparing dry weight before and after fat extraction with petroleum-ether (Leshner et al., 1972).

In situ hybridization. Brains were removed immediately after decapitation between 8:00 A.M. and 12:00 P.M., frozen in a bed of crushed dry ice, sectioned in a coronal plane at $14 \mu \mathrm{m}$ with a cryostat, mounted on RNase-free slides, and treated with $4 \%$ paraformaldehyde, acetic anhydride, ethanol, and chloroform. For each animal, four to six slides (12 brain sections) containing hypothalamus were selected for hybridization. All brain slices were concurrently prepared for hybridization and used in the same assay for each probe. Riboprobes for peptide mRNAs were transcribed in the presence of ${ }^{33} \mathrm{P}-\mathrm{UTP}$ from cDNA templates for NPY, $\mathrm{CRH}, \mathrm{POMC}$, and CART. Unincorporated label was separated using a QIAquick nucleotide removal kit (Qiagen, Santa Clarita, CA). Melting temperature calculations assume that the transcription reaction produced full-length transcripts. Hybridization to CRH mRNA was performed on sections from the paraventricular nucleus. For hybridization to NPY 

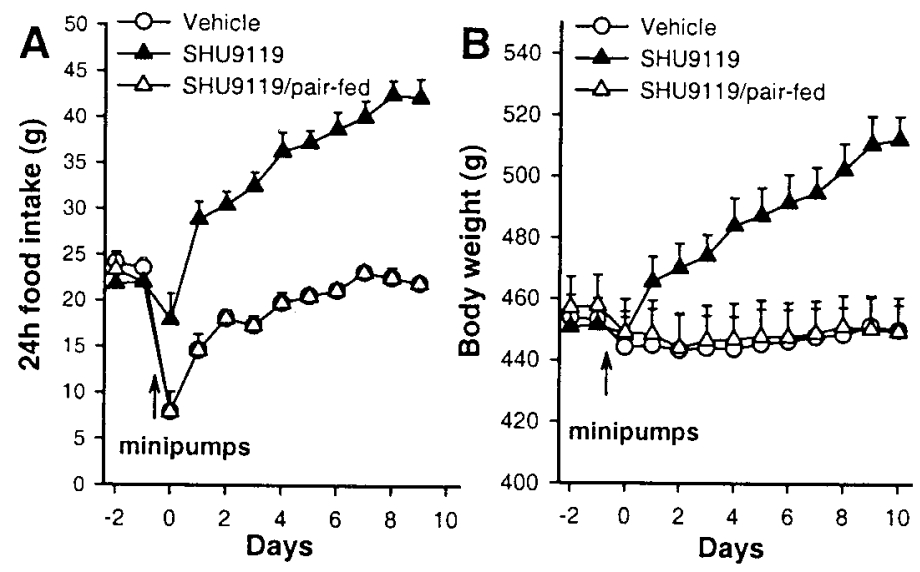

Figure 1. Effect of third cerebroventricular (i3vt) treatment for $11 \mathrm{~d}$ with vehicle (saline; $n=7)$, SHU9119 $(0.5 \mathrm{nmol} / \mathrm{d} ; n=7)$, or SHU9119 $(0.5$ $\mathrm{nmol} / \mathrm{d}$ ) pair-fed to the vehicle-treated group (SHU9119/pair-fed; $n=7$ ) on $24 \mathrm{hr}$ food intake $(A)$ and body weight $(B)$. Both food intake $(p<$ 0.0001 from day 2 till the end of treatment) and body weight $(p<0.05$, days $2-7 ; p<0.01$, days $8-10$ ) were significantly increased in i3vt SHU9119-treated animals compared with the i3vt vehicle-treated group.

mRNA, sections were selected from the midregion of the rostrocaudal extent of the arcuate nucleus (which also contains the dorsomedial and ventromedial nuclei), based on our previous experience that NPY mRNA responses to fasting (Marks et al., 1992) and to leptin (Schwartz et al., 1996) are especially robust in this area. For similar reasons, sections for POMC mRNA were selected from the rostral ARC (Schwartz et al., 1997), whereas CART mRNA hybridization was performed on sections from the midregion of the arcuate nucleus adjacent to those selected for NPY. Where possible, hybridization to NPY mRNA was also determined in the hypothalamic dorsomedial nucleus.

Quantitation. The hybridization signal in the ARC of each brain slice was determined from autoradiograms using a phosphoimager system that measures the product of the density and area of the hybridization signal. For each section, the background hybridization signal (measured in an area of the hypothalamus without specific hybridization) was subtracted from the value measured in the target area (e.g., in the arcuate nucleus). The resultant mRNA hybridization value reported for each animal is the mean of $8-12$ sections measured per animal. The anatomical equivalence of hypothalamic sections among animals was obtained by selecting slides (viewed with a dark-field stereomicroscope) with the aid of a rat brain atlas before hybridization. Values of mRNA for each animal are expressed as percentage of the mean value of the vehicle-treated controls fed ad libitum.

Statistical analyses. Results are presented as mean \pm SEM, two-way ANOVA was used for analyses of body weight, food and water intake, core temperature, and locomotor activity, with treatment conditions as between-subject factors (vehicle vs SHU9119 vs SHU9119/pair-fed) and time as repeated measures (13 factors: days $-2 / 10)$. Further data analysis included standard one-way ANOVA with three levels (vehicle vs SHU9119 vs SHU9119/pair-fed), and a post hoc $t$ test for independent measures was used to test the significance at each time point $(p<0.05)$. A paired sample $t$ test for dependent measures was used to test significance $(p<0.05)$ between body temperature and locomotor activity assessed during baseline and during treatment. Pearson's test was used to detect significant correlation between body temperature and locomotor activity of the last $5 \mathrm{~d}$ of treatment and between plasma levels of leptin and expression levels of various hypothalamic neuropeptides.

\section{RESULTS}

\section{Food and water consumption and body weight}

The effect of chronic i3vt administration of SHU9119 on daily food intake $(A)$ and body weight $(B)$ changes are shown in Figure 1. ANOVA revealed significant interaction effects on food intake (time $\times$ treatment: $\left.F_{(22,198)}=13.0 ; p<0.0001\right)$ and body weight (time $\times$ treatment: $\left.F_{(24,216)}=24.0 ; p<0.0001\right)$. Post hoc analyses revealed that food intake as well as body weight were dramatically increased in the ad libitum fed SHU9119-treated group relative to vehicle controls. ANOVA revealed significant interaction effects on water intake (time $\times$ treatment: $F_{(22,198)}=10.1 ; p<0.0001$; data not shown) that appeared to follow the changes in food intake. No differences were observed between body weights of vehicle-treated and SHU9119-treated rats that were pair-fed to controls. Intraperitoneally implanted pumps delivering SHU9119 in a dose equal to that given centrally did not alter food intake $\left(F_{(10,80)}=0.746 ; p=0.679\right)$, water intake $\left(F_{(10,80)}=1.17 ; p=\right.$ $0.323)$ and body weight $\left(F_{(10,80)}=0.887 ; p=0.549\right)$ relative to animals treated intraperitoneally with saline.

\section{Body composition}

Table 1 shows body composition of i3vt vehicle-treated, SHU9119treated, and SHU9119-treated/pair-fed animals at the beginning of the light phase on day 11 of treatment. ANOVA revealed effects of treatment on total body weight $\left(F_{(2,18)}=15.5 ; p<0.0001\right)$, eviscerated carcass wet weight $\left(F_{(2,18)}=3.8 ; p<0.05\right)$, and weights of the liver $\left(F_{(2,18)}=34.05 ; p<0.0001\right)$, gastrointestinal tract $\left(F_{(2,18)}=\right.$ 25.28; $p<0.0001)$, and gastrointestinal filling $\left(F_{2,18}=28.11 ; p<\right.$ 0.0001 ), which were only significantly higher in the SHU9119treated animals relative to controls. Weights of retroperitoneal $\left(F_{(2,18)}=26.4 ; p<0.0001\right)$ and epididymal $\left(F_{(2,18)}=8.3 ; p<\right.$ $0.001)$ fat pads were higher in both SHU9119-treated and SHU9119-treated/pair-fed animals relative to controls. Table 2 shows results of fat extraction analyses. Fat content of the eviscerated carcass $\left(F_{(2,18)}=35.67 ; p<0.0001\right)$, liver $\left(F_{(2,18)}=13.30 ; p<\right.$ $0.0001)$, and gastrointestinal tract $\left(F_{(2,18)}=55.73 ; p<0.0001\right)$ were only increased in the SHU9119-treated ad libitum-fed animals relative to those in vehicle-treated controls, but not in SHU9119 treated/pair-fed animals. Fat content of abdominal fat pads $\left(F_{(2,18)}=25.99 ; p<0.0001\right)$ and body fat content expressed as absolute fat mass of total body $\left(F_{(2,18)}=47.36 ; p<0.0001\right)$ and expressed as percentage of body fat of total body $\left(F_{(2,18)}=49.60\right.$; $p<0.0001$ ) were higher in both SHU9119-treated and SHU9119treated/pair-fed animals relative to controls. Thus, SHU9119 increased body fat content over vehicle-treated animals consuming the same amount of food. Intraperitoneal SHU9119 treatment did not alter any of these parameters relative to animals intraperitoneally treated with saline.

\section{Temperature and locomotor activity}

From day 5 on, body temperature of vehicle-treated animals during the light phase had returned to preinfusion levels, indicating recovery from the effect of pump implantation. Mean values of both temperature and activity measured in the light and dark cycles from day 5-10 for each group are shown in Figure 2. Although vehicle treatment tended to increase the activity level during the dark and light phase, this effect was not significant when analyzed by a paired sample $t$ test comparing preinfusion activity levels with those obtained over days 5-10. The slight increase was mainly attributable to two animals, which, in the event of exclusion from the ANOVA, did not primarily affect the outcome of treatment effects across all groups. During the dark phase, ANOVA revealed a significant effect on body temperature $\left(F_{(2,18)}=20.3 ; p<0.0001\right)$ and locomotor activity $\left(F_{(2,18)}=6.2\right.$; $p=0.009)$. Post hoc analyses revealed that body temperatures of SHU9119-treated ad libitum-fed animals $(p<0.0001)$ as well as of SHU9119-treated/pair-fed animals $(p<0.0001)$ were significantly lower than that of vehicle-treated animals during the dark cycle. No differences were observed between the two SHU9119treated groups. Post hoc analysis revealed lower locomotor activ- 


\begin{tabular}{lccc}
\hline \multicolumn{2}{l}{ Table 1. Body composition of experimental rats } & & \\
Treatment & Vehicle & SHU9119 & SHU9119/pair-fed \\
\hline Total weight & $450.1 \pm 8.2$ & $512.3 \pm 7.7^{* * *}$ & $449.5 \pm 11.3$ \\
Eviscerated carcass & $364.6 \pm 6.7$ & $387.2 \pm 5.1^{*}$ & $361.8 \pm 9.2$ \\
Liver & $15.5 \pm 0.4$ & $21.0 \pm 0.8^{* *}$ & $15.0 \pm 0.5$ \\
Gastrointestinal tract (empty) & $17.9 \pm 0.8$ & $26.9 \pm 1.3^{* * *}$ & $19.9 \pm 0.7$ \\
Gastrointestinal filling & $17.6 \pm 1.6$ & $37.7 \pm 2.5^{* * *}$ & $19.1 \pm 2.1$ \\
Retroperitoneal fat & $4.5 \pm 0.8$ & $11.2 \pm 0.7^{* * *}$ & $6.7 \pm 0.5^{*}$ \\
Epididymal fat & $7.4 \pm 0.6$ & $10.9 \pm 0.6^{* * *}$ & $9.3 \pm 0.7^{*}$
\end{tabular}

Wet weights are means \pm SE expressed in grams. Rats received third cerebroventricular (i3vt) treatment for $11 \mathrm{~d}$ with vehicle (saline; $n=7)$, SHU9119 $(0.5 \mathrm{nmol} / \mathrm{d} ; n=7)$, or SHU9119 $(0.5 \mathrm{nmol} / \mathrm{d})$ pair-fed with the vehicle-treated group (SHU9119/pair-fed; $n=7$ ). ${ }^{*} p<0.05 ; * *<<0.01$, and ${ }^{* * *} p<0.001$ denote statistical difference with the i3vt vehicle-treated group.

Table 2. Fat contents after fat extraction procedure

\begin{tabular}{lccc} 
Treatment & Vehicle & SHU9119 & SHU9119/pair-fed \\
\hline Total body fat & $46.6 \pm 3.3$ & $96.4 \pm 2.7^{* * *}$ & $59.0 \pm 5.0^{*}$ \\
Total fat as \% body weight & $10.8 \pm 0.7$ & $20.3 \pm 0.5^{* * *}$ & $13.6 \pm 0.9^{*}$ \\
Eviscerated carcass & $31.8 \pm 2.9$ & $66.0 \pm 2.3^{* * *}$ & $39.9 \pm 3.7$ \\
Liver & $0.6 \pm 0.3$ & $1.6 \pm 0.2^{* *}$ & $0.3 \pm 0.1$ \\
Gastrointestinal tract & $4.9 \pm 0.4$ & $9.5 \pm 0.3^{* * *}$ & $5.5 \pm 0.4$ \\
Abdominal fat pads & $9.4 \pm 1.0$ & $19.4 \pm 0.9^{* * *}$ & $13.3 \pm 1.0^{*}$
\end{tabular}

Weights are means \pm SE expressed in grams. Rats received third cerebroventricular (i3vt) treatment for $11 \mathrm{~d}$ with vehicle (saline; $n=7)$, SHU9119 $(0.5 \mathrm{nmol} / \mathrm{d} ; n=7)$, or SHU9119 $(0.5 \mathrm{nmol} / \mathrm{d})$ pair-fed with the vehicle-treated group (SHU9119/pair-fed; $n=7$ ). ${ }^{*} p<0.05,{ }^{* *} p<0.01$, and ${ }^{* * *} p<0.001$ ) denote statistical difference with the i3vt vehicle-treated group.
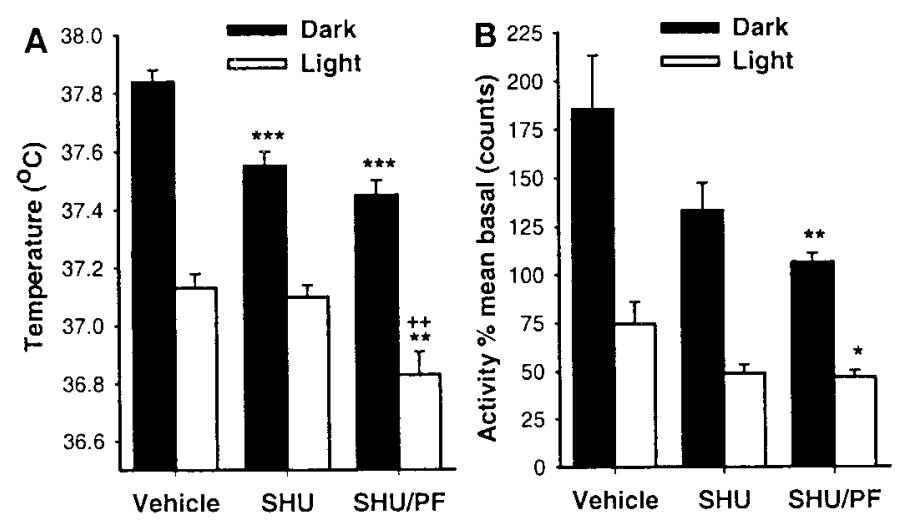

Figure 2. Five day averages (days 5-10 after minipumps implantation) of body temperature $(A)$ and locomotor activity $(B)$ during the dark and light phase of rats treated third cerebroventricularly (i3vt) with vehicle (saline; $n=7)$, SHU9119 $(0.5 \mathrm{nmol} / \mathrm{d} ; n=7)$, or SHU9119 $(0.5 \mathrm{nmol} / \mathrm{d})$ pair-fed with the vehicle-treated group (SHU9119/pair-fed, $n=7$ ). ${ }^{*} p<$ $0.05) ;{ }^{* *} p<0.01 ; * * * p<0.001$ denote statistical difference with the i3vt vehicle-treated group. ${ }^{++} p<0.01$ denotes statistical difference with the i3vt SHU9119-treated group.

ity ( $p=0.007$ ) of SHU9119-treated pair-fed animals relative to that of vehicle control animals. ANOVA also revealed significant effects of treatments on the $5 \mathrm{~d}$ averages of body temperature $\left(F_{(2,18)}=7.8 ; p=0.004\right)$ and locomotor activity $\left(F_{(2,18)}=4.4 ; p=\right.$ $0.027)$ during the light phase. SHU9119-treated/pair-fed animals had a lower light phase temperature relative to SHU9119-treated ad libitum animals $(p=0.009)$ as well as relative to controls $(p=$ $0.008)$. Only locomotor activity displayed by the pair-fed group was lower $(p=0.038)$ than that displayed by controls. Intraperitoneal SHU9119 treatment did not alter body temperature $\left(F_{(1,8)}=1.889 ; p=0.207\right)$ and activity $\left(F_{(1,8)}=2.777 ; p=0.134\right)$ during the light phase nor during the dark phase $\left(F_{(1,8)}=0.944\right.$; $p=0.360$ and $F_{(1,8)}=0.012 ; p=0.917$ for temperature and activity, respectively) of animals relative to these parameters in animals treated intraperitoneally with saline.

Pearson's test revealed a significant correlation of body temperature with locomotor activity of animals across all treatment groups during the dark phase $(r=0.63 ; p=0.01)$, but not in the light phase $(r=0.34$; NS).

\section{Plasma analyses}

Table 3 shows the plasma concentrations of fuels and hormones and the hepatic glycogen content of i3vt vehicle-treated, SHU9119-treated, and SHU9119-treated/pair-fed animals at the beginning of the light phase on the last day of treatment. ANOVA revealed significant treatment effects on plasma levels of insulin $\left(F_{(2,18)}=19.9 ; p<0.0001\right)$, glucagon $\left(F_{(2,18)}=21.8 ; p<0.0001\right)$, leptin $\left(F_{(2,18)}=68.0 ; p<0.0001\right)$, cholesterol $\left(F_{(2,18)}=14.78 ; p<\right.$ $0.0001)$, and on total hepatic glycogen content $\left(F_{(2,18)}=6.1 ; p<\right.$ $0.01)$. No treatment effects were found on plasma levels of triglycerides, free fatty acids, corticosterone, and glucose. Post hoc analysis revealed that, relative to vehicle-treated animals, SHU9119-treated rats have higher levels of plasma cholesterol, leptin, insulin, glucagon, and total hepatic glycogen. Relative to vehicle-treated controls, plasma cholesterol and leptin levels were also elevated in SHU9119-treated animals that were pair-fed to controls. Intraperitoneal SHU9119 treatment failed to have an effect on any of these parameters relative to intraperitoneal or i3vt saline treatment.

\section{In situ hybridization}

Figure 3 shows the results of in situ hybridization (presented as percentage of expression of mean value of the vehicle-treated group) of mRNA for NPY, POMC, and CART in the arcuate 
Table 3. Plasma concentrations of fuel, hormones, and hepatic glycogen of experimental rats

\begin{tabular}{lccc} 
Treatment & Vehicle & SHU9119 & SHU9119/pair-fed \\
\hline Glucose, mmol/l & $6.67 \pm 0.50$ & $7.23 \pm 0.38$ & $6.18 \pm 0.28$ \\
Triglycerides, mmol/1 & $1.57 \pm 0.20$ & $1.06 \pm 0.16$ & $1.30 \pm 0.10$ \\
Free fatty acids, mmol/1 & $0.25 \pm 0.02$ & $0.23 \pm 0.02$ & $0.20 \pm 0.01$ \\
Cholesterol, mmol/1 & $1.66 \pm 0.09$ & $2.45 \pm 0.10^{* * *}$ & $2.18 \pm 0.13^{* *}$ \\
Insulin, pmol/1 & $0.90 \pm 0.08$ & $3.21 \pm 0.48^{* * *}$ & $0.98 \pm 0.16$ \\
Glucagon, ng/l & $93.29 \pm 7.38$ & $169.0 \pm 8.78^{* * *}$ & $97.00 \pm 5.96$ \\
Corticosterone, nmol/1 & $103.48 \pm 39.65$ & $111.81 \pm 23.51$ & $136.10 \pm 18.24$ \\
Leptin, $\mu \mathrm{g} / 1$ & $4.91 \pm 0.65$ & $29.02 \pm 2.34^{* * *}$ & $10.03 \pm 1.10^{* *}$ \\
Total hepatic glycogen, gm & $1.09 \pm 0.06$ & $1.53 \pm 0.14^{* *}$ & $1.09 \pm 0.09$
\end{tabular}

Values are means \pm SE. Rats received third cerebroventricular (i3vt) treatment for $11 \mathrm{~d}$ with vehicle $($ saline; $n=7)$, SHU9119 $(0.5 \mathrm{nmol} / \mathrm{d} ; n=7)$, or SHU9119 $(0.5 \mathrm{nmol} / \mathrm{d})$ and were pair-fed with the vehicle-treated group (SHU9119/pairfed; $n=7)$. ${ }^{* *} p<0.01$ and ${ }^{* * *} p<0.001$ denote statistical difference with the i3vt vehicle-treated group.

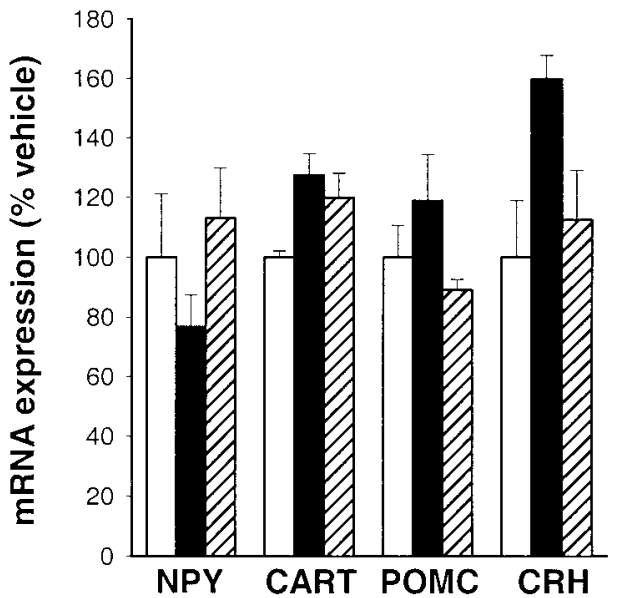

Figure 3. Expression of mRNA for NPY, CART, and POMC in the arcuate hypothalamic nucleus, and $\mathrm{CRH}$ in the paraventricular nucleus of rats treated third cerebroventricularly (i3vt) for $11 \mathrm{~d}$ with vehicle (saline; $n=7$; open bars $)$, SHU9119 ( $0.5 \mathrm{nmol} / \mathrm{d} ; n=7$; black bars $)$, or SHU9119 $(0.5 \mathrm{nmol} / \mathrm{d})$ pair-fed with the vehicle-treated group (SHU9119/pair-fed; $n=7$; hatched bars). Levels of mRNA were expressed as percentage of expression of mean value of the vehicle-treated group.

hypothalamic nucleus and for $\mathrm{CRH}$ in the paraventricular nucleus of i3vt vehicle-treated, SHU9119-treated, and SHU9119-treated/ pair-fed animals at the beginning of the light phase on day 11 of treatment. No NPY mRNA expression was observed in the dorsomedial hypothalamic nucleus.

Overall ANOVAs did not reveal statistical significant differences in expression levels of NPY, POMC, CART, or CRH mRNA across all groups. However, consistent with regulatory effects of leptin on the expression profiles of these neuropeptides, Pearson's test revealed significant positive correlations of plasma leptin of animals across the three treatment groups with expression of prepromRNA for CRH $(r=0.51 ; p=0.03)$, CART $(r=$ $0.49 ; p=0.04)$, and POMC $(r=0.50 ; p=0.03)$.

\section{DISCUSSION}

The present study investigated the effect of $11 \mathrm{~d}$ of third intracerebroventricular (i3vt) administration of the MC receptor (type 3 and 4) antagonist SHU9119 on various behavioral, hormonalmetabolic, and neuroendocrine mechanisms important to regulation of energy balance. As predicted, i3vt SHU9119 treatment produced, in rats allowed to augment their food intake, a dramatic increase of body weight $(\sim 14 \%)$ and plasma leptin levels $(\sim 490 \%)$ relative to controls. The increase in body weight in SHU9119-treated animals relative to controls was primarily attributable to markedly increased $(\sim 90 \%)$ fat deposition. The doubling of food intake in SHU9119-treated animals obviously contributed importantly to their weight gain. By including a group of SHU9119-treated animals that was pair-fed to vehicle-treated controls, we were able to distinguish those responses to chronic $\mathrm{MC}$ receptor blockade from the ones that were secondary to the increased food intake. For example, although SHU9119 treatment led to increased levels of plasma insulin, glucagon, and hepatic glycogen content relative to those in controls, these values were caused by overfeeding because they were normalized by pair feeding of i3vt SHU9119-treated animals to vehicle-treated controls. Some responses to central MC receptor blockade, however, were not completely reversed by pair feeding of SHU9119-treated animals to controls. Although their body weight did not increase detectably, i3vt SHU9119/pair-fed animals still exhibited a 27\% increase in fat mass (vs 90\% increase in ad libitum SHU9119treated animals) and a 104\% increase in plasma leptin levels (vs $490 \%$ in ad libitum SHU9119-treated animals) relative to controls. The increased leptin secretion is likely secondary to the residual increase seen in the fat depot size in SHU9119-treated/ pair-fed animals relative to controls, if leptin secretion is subject to autoregulation as part of an "adipostat" pathway.

The most pronounced effects of i3vt SHU9119 treatment that were independent of increased food intake were reductions in body temperature and spontaneous activity and an increase in plasma cholesterol levels (relative to controls: 31 and $48 \%$ increases in pair-fed and ad libitum feeding SHU9119-treated animals, respectively). Although the specific fraction of lipoprotein cholesterol that was elevated remains to be determined, this is the first demonstration of a CNS intervention that leads to increased plasma levels of total cholesterol in genetically normal rats. Given the importance of high plasma total cholesterol as well as an obese phenotype in the pathogenesis of artherosclerotic vascular disease, the possibility that reduced CNS MC receptor signaling may have relevant clinical consequences can be considered. Because we did not find an effect of peripheral SHU9119 treatment on any parameter assessed, we can rule out the possibility that the central effects that we observed involve an action of melanocortin receptor blockade in peripheral tissues (i.e., by leakage from the CNS into the general circulation). Thus, these data strongly implicate the brain as the site where reduced melanocortin receptor activity leads to obesity and its associated metabolic derangements. 
Our results showing that i3vt SHU9119-treated rats fed ad libitum as well as SHU9119-treated/pair-fed animals are more obese and have lower body temperatures relative to controls are consistent with the recent observation in MC4 receptor knockout mice (Ste. Marie et al., 2000). These mice have a metabolic defect that promotes obesity in a similar manner as the SHU9119treated animals in the present study. Because MC3 receptor knock-out mice have an increased fat depot size (Butler et al., 2000; Chen et al., 2000), it might be possible that part of the effect of i3vt SHU9119 to promote obesity is caused via its inhibitory effect on MC3 receptors. The data in the present study are also consistent with rodents with mutations in either leptin synthesis (ob/ob mice) or leptin receptors ( $d b / d b$ mice, $f a / f a$ rats) that are also obese and hypothermic (Campfield et al., 1995; Seeley et al., 1996; Halaas et al., 1997). Because leptin can increase energy expenditure (Halaas et al., 1997; van Dijk et al., 1999), uncoupling protein synthesis in various peripheral tissues (Halaas et al., 1997; Scarpace et al., 1997; Zhou et al., 1997), and body temperature (Halaas et al., 1997) via actions in the CNS, pharmacological blockade of CNS pathways downstream from leptin signaling might be expected to lower body temperature, and $\mathrm{MC}$ receptor signaling is implicated in at least some of these responses (Satoh et al., 1998). Because SHU9119-treated/pair-fed animals had lower spontaneous activity levels compared with controls, it might be possible that this effect also contributed to the lower body temperature of this group. The fact that locomotor activity and body temperature (particularly during the dark phase when animals display the greatest spontaneous activity) were strongly correlated across all treatment groups raises the interesting possibility that reduced physical activity contributes to increased weight gain in response to pharmacological blockade of CNS MC receptors.

Within the anatomical range across the arcuate and the paraventricular nucleus that we selected, SHU9119 treatment in the present study failed to significantly alter expression levels of neuropeptides involved in regulation of energy balance. One implication of this observation might be that the obese phenotype as a result of CNS MC3/4 receptor blockade is independent of some hypothalamic neuropeptide responses (i.e., reduced mRNA for CRH, POMC, and CART, and increased mRNA for NPY) anticipated to underlie weight gain. In fact, there were tendencies of SHU9119 treatment to increase paraventricular hypothalamic expression of CRH mRNA and arcuate hypothalamic expression of POMC and CART mRNA relative to control treatment. In addition, there was a tendency of SHU9119 treatment to reduce expression of neuropeptide $\mathrm{Y}$ mRNA in the arcuate nucleus, although none of these effects achieved statistical significance. Because increased CRH (Hotta et al., 1991; Buwalda et al., 1997), and CART (Kristensen et al., 1998) signaling and reduced NPY (Myers et al., 1995) signaling all have anorexigenic actions and promote leanness, these can be considered as compensatory responses to the positive energy status of the SHU9119-treated animals. Consistent with this view is the finding in the present study of significant positive correlations of animals across all three groups between the plasma leptin concentration and expression of mRNA encoding for CRH, CART, and for POMC.

Despite careful analysis, there was no evidence of hypothalamic NPY mRNA expression in the dorsomedial hypothalamic nucleus. This is consistent with a recent study of Singer et al. (2000), showing that NPY mRNA is only expressed in the dorsomedial hypothalamus in very young rats and disappears after $30 \mathrm{~d}$ of age. Thus, the increased NPY mRNA expression found in the dorsomedial nucleus of adult genetically obese $\mathrm{A}^{\mathrm{Y}}$ or MC4 receptor knock-out mice (Kesterson et al., 1997) might be speciesspecific and not relevant for the etiology of obesity because of reduced CNS melanocortin signaling in the rat.

In summary, the results of the present study provide clear additional evidence that inhibition of CNS MC receptor activity leads to obesity and hypercholesterolemia and that food intakeindependent mechanisms contribute to this phenomenon. The data furthermore show that hypothermic and attenuated spontaneous activity effects of reduced CNS MC receptor activity are independent of food intake and likely promote increased fat deposition and increases of plasma leptin levels in pair-fed animals. In addition, i3vt SHU9119 treatment tended to increase expression of hypothalamic neuropeptides (at least in the anatomical range that we selected) that promote leanness $(\mathrm{CRH}$, CART, POMC) and to reduce one that promotes weight gain (NPY). Thus, these data seem to suggest that the brain melanocortin system might not be a pivotal step linking leptin signaling to altered activity of hypothalamic pathways that contain $\mathrm{CRH}$, CART, POMC, and NPY. Rather, our findings support the view that these systems are regulated by leptin in parallel (Boston et al., 1997) and that interventions that influence energy balance via one pathway elicit compensatory responses from the others.

\section{REFERENCES}

Boston BA, Blaydon KM, Varnerin J, Cone RD (1997) Independent and additive effects of central POMC and leptin pathways on murine obesity. Science 28:1641-1644.

Butler AA, Kesterson RA, Khong K, Cullen MJ, Pelleymounter MA, Dekoning J, Baetscher M, Cone RD (2000) A unique metabolic syndrome causes obesity in the melanocortin-3 receptor-deficient mouse. Endocrinology 141:3518-3521.

Buwalda B, de Boer SF, Van Kalkeren AA, Koolhaas JM (1997) Physiological and behavioral effects of chronic intracerebroventricular inf usion of corticotropin-releasing factor in the rat. Psychoneuroendocrinology 22:297-309.

Campfield LA, Smith FJ, Guisez Y, Devos R, Burn P (1995) Recombinant mouse $\mathrm{OB}$ protein: evidence for a peripheral signal linking adiposity and central networks. Science 269:546-549.

Chen AS, Marsh DJ, Trumbauer ME, Frazier EG, Guan X-M, Yu H, Rosemblum CI, Vongs A, Feng Y, Cao L, Metzger JM, Strack AM, Camacho RE, Mellin TN, Nunes CN, Min W, Fisher J, Gopal-Truter S, MacIntyre DE, Chen HY, Van der Ploeg HT (2000) Inactivation of the mouse melanocortin-3 receptor results in increased fat mass and reduced lean body mass. Nat Genet 26:97-102.

Cheng D, Garg A (1999) Monogenic disorders of obesity and body fat distribution. J Lipid Res 40:1735-1746.

Comuzzie AG, Hixson JE, Almasy L, Mitchell BD, Mahaney MC, Dyer TD, Stern MP, MacCluer JW, Blangero J (1997) A major quantitative trait locus determining serum leptin levels and fat mass is located on human chromosome 2. Nat Genet 15:273-276.

Cornelius P, Hedde JR, Newsome WP, Boyd JG, Hargrove DM, Martin KA, Patterson TA (1999) The role of central melanocortin receptors in the regulation of metabolic rate. Abstract of the 81st Endocrine Society Meeting, April, San Diego.

Dawson Jr R, Kontur P, Monjanr A (1984) High-performance liquid chromatographic (HPLC) separation and quantitation of endogenous glucocorticoids after solid-phase extraction from plasma. Horm Res 20:89-94.

Fan W, Boston BA, Kesterson RA, Hruby WJ, Cone RD (1997) Role of melanocortinergic neurons in feeding and in the agouti obesity syndrome. Nature 385:165-168.

Gu W, Tu Z, Kleyn PW, Kissebah A, Duprat L, Lee J, Chin W, Maruti S, Deng N, Fisher SL, Franco LS, Burn P, Yagaloff KA, Nathan J, Heymsfield S, Albu J, Pi-Sunyer FX, Allison DB (1999) Identification and functional analysis of novel human melanocortin-4 receptor variants. Diabetes 489:635-639.

Halaas JL, Boozer C, Blair-West J, Fidahuisein N, Denton DA, Friedman JM (1997) Physiological response to long-term peripheral and central leptin infusion in lean and obese mice. Proc Natl Acad Sci USA 94:8878-8883.

Haynes WG, Morgan DA, Djalali A, Sivitz WI, Mark AL (1999) Interaction between the melanocortin system and leptin in control of sympathetic nerve traffic. Hypertension 33:542-547.

Hinney A, Schmidt A, Nottebom K, Heibult O, Becker I, Ziegler A, 
Gerber G, Sina M, Gorg T, Mayer H, Siegfied W, Fichter M, Remschmidt H, Hebebrand J (1999) Several mutations in the melanocortin-4 receptor gene including a nonsense and a frameshift mutation associates with dominantly inherited obesity in humans. J Clin Endocrinol Metab 84:1483-1486.

Hixson JE, Almasy L, Cole S, Birnbaum S, Mitchell BD, Mahaney MC, Stern MP, MacCluer JW, Blangero J, Comuzzie AG (1999) Normal variation in leptin levels is associated with polymorphisms in the proopiomelanocortin gene, POMC. J Clin Endocrinol Metab 84:3187-3191.

Hotta M, Shibasaki T, Yamauchi N, Ohno H, Benoit R, Ling N, Demura $\mathrm{H}$ (1991) The effects of chronic central administration of corticotropinreleasing factor on food intake, body weight, and hypothalamic-pituitaryadrenocortical hormones. Life Sci 48:1483-1491.

Huszar D, Lynch CA, Fairchild-Huntress CA, Dunmore JH, Fang Q, Berkemeier LR, Gu W, Kesterson RA, Boston BA, Cone RD, Smith FJ, Campfield LA, Burn P, Lee F (1997) Target disruption of the melanocortin-4 receptor result in obesity in mice. Cell 88:131-141.

Kask A, Rago L, Korrovits P, Wikberg JE, Schioth HB (1998) Evidence that the orexigenic effects of melanocortin 4 receptor antagonist (HS014) are mediated by neuropeptide Y. Biochem Biophys Res Commun 248:245-249.

Kesterson RA, Huszar D, Lynch CA, Simerly RB, Cone RD (1997) Induction of neuropeptide $\mathrm{Y}$ gene expression in the dorsal medial hypothalamic nucleus in two models of the agouti obesity syndrome. Mol Endocrinol 11:630-637.

King PJ, Widdowson PS, Doods H, Williams G (2000) Regulation of neuropeptide Y release from hypothalamic slices by melanocortin-4 agonists and leptin. Peptides 21:45-48.

Kristensen P, Judge ME, Thin L, Ribel U, Christjansen KN, Wulff BS, Clausen JT, Jensen PB, Madsen OD, Vrang N, Larsen PJ, Hastrup S (1998) Hypothalamic CART is a new anorectic peptide regulated by leptin. Nature 393:72-76.

Krude H, Bierbermann H, Luck W, Horn R, Brabant G, Gruters A (1998) Severe early-onset obesity, adrenal insufficiency and red hair pigmentation caused by POMC mutation in humans. Nat Genet 19:155-157.

Leshner AI, Litwin VA, Squibb RL (1972) A simple method for carcass analysis. Physiol Behav 9:281-282.

Marks JL, Li M, Schwartz MW, Porte D Jr, Baskin DG (1992) Effect of fasting on regional levels of neuropeptide Y mRNA and insulin receptors in the rat hypothalamus: an autoradiographic study. Mol Cell Neurosci 3:199-205.

Marsh DJ, Hollopeter G, Huszar D, Laufer R, Yagaloff KA, Fisher SL, Burn P, Palmiter RD (1999) Response of melanocortin-4 receptordeficient mice to anorectic and orexigenic peptides. Nat Genet 21:119-122.

Miltenberger RJ, Mynatt RL, Wilkinson JE, Woychik RP (1997) The role of the agouti gene in the yellow obese syndrome. J Nutr 127:1902S-1907S.

Myers RD, Wooten MH, Ames CD, Nyce JW (1995) Anorexic action of a new potential neuropeptide $\mathrm{Y}$ antagonist [D-Tyr27,36,D-Thr32\}NPY (27-36) infused into the hypothalamus of the rat. Brain Res Bull $37: 237-245$.

Satoh N, Ogawa Y, Katsuura G, Numata Y, Mazuzaki H, Yoshimasa Y, Nakao K (1998) Satiety effect and sympathetic activation of leptin are mediated by hypothalamic melanocortin system. Neurosci Lett 249:107-110.

Scarpace PJ, Matheny M, Pollock BH, Tuner N (1997) Leptin increases uncoupling protein expression and energy expenditure. Am J Physiol 273:E226-E229.
Schwartz MW, Baskin DG, Bukowski TR, Kuijper JL, Foster D, Lasser G, Prunkard DE, Porte Jr D, Woods SC, Seeley RJ, Weigle DS (1996) Specificity of leptin action on elevated blood glucose levels and hypothalamic neuropeptide Y gene expression in ob/ob mice. Diabetes 45:531-535.

Schwartz MW, Seeley RJ, Woods SC, Welgle DS, Campfield LA, Burn P, Baskin DG (1997) Leptin increases hypothalamic pro-opiomelanocortin mRNA expression in the rostral arcuate nucleus. Diabetes 46:2119-2123.

Schwartz MW, Woods SC, Porte D Jr, Seeley RJ, Baskin DG (2000) Central nervous system control of food intake. Nature 404:661-671.

Seeley RJ, van Dijk G, Campfield LA, Smith FJ, Burn P, Nellingan JA, Bell JM, Baskin DG, Woods SC, Schwartz MW (1996) Intraventricular leptin reduces food intake and body weight of lean rats but not obese Zucker rats. Horm Met Res 28:664-668.

Seeley RJ, Yagaloff KA, Fisher SL, Burn P, Thiele TE, van Dijk G, Baskin DG, Schwartz MW (1997) Melanocortin receptors in leptin effects. Nature 390:349.

Singer LK, Kuper J, Brogan RS, Smith MS, Grove KL (2000) Novel expression of hypothalamic neuropeptide Y during postnatal development in the rat. NeuroReport 11:1075-1085.

Skuladottir GV, Jonsson L, Skarphedinsson JO, Mutulis F, Muceniece R, Raine A, Mutule I, Helgason J, Prusis P, Wikberg JES, Schiöth HB (1999) Long term orexigenic effect of a novel melanocortin 4 receptor selective antagonist. Br J Pharmacol 126:27-34.

Stanley BG, Kyrokouli SE, Lampert S, Leibowitz SF (1986) Neuropeptide Y chronically injected into the hypothalamus: a powerful neurochemical inducer of hyperphagia and obesity. Peptides 7:1189-1192.

Ste. Marie L, Miura GI, Marsh DJ, Yagaloff K, Palmiter R (2000) A metabolic defect promotes obesity in mice lacking melanocortin-4 receptors. Proc Natl Acad Sci USA 97:12339-12344.

Thornton JE, Cheung CC, Clifton DK, Steiner RA (1997) Regulation of hypothalamic proopiomelanocortin mRNA by leptin in ob/ob mice. Endocrinology 138:5063-5066.

Van Dijk G, Thiele TE, Donhahey LA, Campfield FJ, Smith P, Burn P, Bernstein IL, Wood SC, Seeley RJ (1996) Central infusion of leptin and GLP-1(7-36) amide differentially stimulate c-FLI in the rat brain. Am J Physiol 271:R1096-R1100.

Van Dijk G, Seeley RJ, Thiele TE, Friedman MI, Ji H, Wilkinson CW, Burn P, Campfield LA, Tenebaum R, Baskin DG, Woods SC, Schwartz MW (1999) Metabolic, gastrointestinal, and CNS neuropeptide effects of brain leptin administration in the rat. Am J Physiol 276:R1425-R1433.

Yaswen L, Diehl N, Brennan MB, Hochgeschwender U (1999) Obesity in the mouse model of pro-opiomelanocortin deficiency responds to peripheral melanocortin. Nat Med 5:1066-1070.

Yen TT, Gill AM, Frigeri LG, Barsh GS, Wolff GS (1994) Obesity, diabetes and neoplasia in yellow $\mathrm{A}^{\mathrm{y}} /$ - mice: ectopic expression of the agouti gene. FASEB J 8:479-488.

Zarjevski N, Cusin I, Vettor R, Rohner-Jeanrenaud F, Jeanrenaud B (1993) Chronic intracerebroventricular neuropeptide-Y administration to normal rats mimics hormonal and metabolic changes of obesity. Endocrinology 133:1753-1758.

Zhang YR, Proenca M, Maffei M, Barone L, Leopold L, Friedman JM (1994) Positional cloning of the mouse obese gene and its humane analogue. Nature 372:425-432

Zhou YT, Shimbukuro M, Koyama K, Lee Y, Wang MY, Trieu F, Newgard CB, Unger RH (1997) Induction by leptin of uncoupling protein-2 and enzymes of fatty acid oxidation. Proc Natl Acad Sci USA 91:6386-6390 